\title{
EUROPEAN MONETARY UNION: ACHIEVEMENTS AND FUTURE CHALLENGES
}

\section{İrem ZEYNELOĞLU*}

\section{Abstract}

The European governance has constantly evolved since the acceptance of the Maastricht Treaty in 1992. The evolution of the European institutions is especially marked by the economic impact of the 2008 crisis. Indeed, following the crisis new institutions with new functions emerged in order to allow for a better management of the crisis. Further reforms are likely to give way to the creation of new institutions in the future, such as the European monetary fund or the European Ministry of Economy and Finance. The present paper analyzes the interaction between the innovations in the functioning of the euro area and the economic business cycles. For this, the present paper first gives the evolution of the key economic indicators in the euro area compared to the USA. Then, the new institutions are analyzed with respect to their economic stabilization capacity. The supra-national character of these new institutions implies higher policy cooperation within the euro area. However, the order of priority assigned to the policy targets seems to be more decisive than the institutional innovation in stabilizing the business cycles.

Keywords: European Union, business cycles, supranational institutions, intergovernmental institutions.

JEL Codes: H12, H77, O52

\section{AVRUPA PARA BİRLİĞİ: BAŞARILAR VE SORUNLAR}

$\ddot{O}_{z}$

1992'de Maastricht Antlaşmasının kabulünden bu yana Avrupa Birliği yönetimi sürekli gelişmiştir. Avrupa kurumlarının bu gelişimi son zamanlarda özellikle 2008 krizinin ekonomik etkileriyle şekillenmiştir. Gerçekten de, 2008 krizini takiben daha etkin bir kriz yönetimine olanak sağlamak amacıyla yeni işlevlere yönelik kurumlar ortaya çıkmıştır. Yeni reformlarla birlikte gelecekte

* Assoc. Prof., Galatasaray University, Department of Economics, e-mail: izeyneloglu@gsu.edu.tr. 
Avrupa Para Fonu ve Avrupa Ekonomi ve Maliye Bakanliğl gibi yeni kurumların ortaya çıkması beklenmektedir. Mevcut çalışma avro bölgesinin işleyişindeki yenilikler ve ekonomik konjonktür arasındaki etkileşimi analiz etmektedir. Bunun için, öncelikle avro bölgesinin temel makroekonomik göstergelerini ABD ile klyaslayarak tartışmakta, sonrasında ise yeni ortaya çıkan ya da oluşturulması düşünülen kurumların ekonomik istikrar sağlama kapasitelerini analiz etmektedir. Yeni kurumların uluslarüstü yaklaşımı avro bölgesinde daha fazla politika işbirliği anlamina gelse de ekonomik istikrar sağlamak konusunda kurumsal yenilikten ziyade politika hedeflerindeki öncelik stralamasının belirleyici olduğu görülmektedir.

Anahtar Kelimeler: Avrupa Birliği, ekonomik konjonktür, uluslarüstü kurumlar, hükümetlerarası kurumlar.

\section{Introduction}

The Maastricht Treaty, which established the European Union (EU) in 1992, foresees the creation of a monetary and economic union with a single currency. For this, starting from 1992, most of the EU countries made considerable efforts to fulfil the conditions required to join the euro area created in 1999 as a last step for the construction of the Union.

The efforts to fulfil these conditions in 1999 and after 2004 have sometimes been costly from the social and economic view. Despite the absence of a major crisis between 1999 and 2007, the economic performance of the European Monetary Union (EMU) especially on growth and unemployment was considered as unsatisfactory by the citizens of the member countries with a performance below the European average. This sentiment of dissatisfaction raised some distrust towards the EU, which increased after the financial crisis which was heavily felt in Europe after 2008¹.

Given the poor economic performance during the period 1999-2007 together with the excessively pragmatic management of the 2008 financial crisis, the European Commission implemented several institutional reforms in order to overcome these weaknesses. Even more fundamental reforms are considered as

\footnotetext{
1 According to the surveys of Eurobarometer (2017: 26) the share of Europeans, who consider the economic outlook in Europe as bad, has increased from 17\% in 2007 to more than $60 \%$ in 2009 . After hitting the record of $77 \%$, this share fell slowly towards $50 \%$ in 2016, which still remains very high compared to the share of the citizens satisfied with the European economy (36\%). In 2010, the share of the citizens who do not trust in the EU (47\%) exceeds the share of those who trust (41\%). The opinion reported in 2017 is similar to the 2010 outcome (Eurobarometer, 2017: 14).
} 
a part of the debate on the future of Europe recently opened by the European Commission (Junker 2015, 2017a).

As a first aim, the present paper intends to assess whether the distrust towards Europe expressed by a non-negligible share of public opinion is justified from the economic point-of-view. For this, the paper analyzes the economic performance of the euro area since 1999 as well as its impact on public finance. Moreover, a second comparison between the evolutions of the key economic variables in the USA to those in EU will serve as a complementary basis for evaluating the economic performance in the euro area. The second aim of the paper is to analyze whether the institutional reforms are likely to increase the capacity of the EU to stabilize economic fluctuations. Indeed, the EU responded to the recent economic crisis by increasing the fiscal discipline in order to improve public finance and by improving coordination within the EU through institutional reforms in order to avoid the recurrence of crises in the future as well as to increase the EU's stabilization capacity. Whether this idea is supported by economic data can be seen by analyzing the economic performance of the euro area in the period following the implementation of new measures on fiscal discipline.

In addition to the fiscal discipline, the improvement of the crisis management appears as a second target of the European authorities after an initial period of quite chaotic management of the 2008 financial crisis. However, measures implemented in view of a better management of the crisis turned out to be insufficient as the reactions to the crisis remained quite pragmatic in the absence of a government at the European level. As a result, new reforms are recommended recently in order to provide the euro area with a fiscal authority endowed with sufficient financial means as well as to promote the Community approach for dealing with problems rather than an intergovernmental approach.

While higher coordination through institutional reforms will certainly allow for more policy implementation at the union level, economic data suggests that the economic stabilization capacity depends rather on the policy objectives. Indeed, the high level as well as the persistence of unemployment in the EU following the crisis could be related to the excessive importance attributed to fiscal discipline.

The paper is organized as follows: section 2 analyzes the economic and financial performance of the euro area countries since 1999 by comparing the achievements to the targeted levels as well as to the key economic indicators of the USA. Section 3 focuses on the decisions of the European Commission regarding the fiscal discipline. Section 4 studies the failure of the crisis management policies following the economic crisis in 2008 and discusses the 
necessity of reforming the steering method of the euro zone. This reform should improve the management of the European economy in normal periods and allow for a better economic stabilization following future crises. Finally, section 5 concludes.

\section{Financial and Economic Performance of the Euro Area}

Table 1 below summarizes the economic performance of the euro zone in terms of growth, unemployment and inflation in the period 1999-2016; a period during which 19 new members joined the EMU. These performances are compared to the targeted values. The aim of price stability is set by the European Treaties. The targeted inflation rate is set by the European Central Bank (ECB) who targets an inflation rate lower than $2 \%$ on a yearly basis. Recently, the ECB redefined its target as being lower than but close to $2 \%$. In contrast to the Fed, the ECB does not target unemployment as a secondary objective. The target of a high level of employment with a high growth rate is mentioned in the European legislation. However, the European legislation imposes at the same time severe constraints regarding public finance and restrains thereby the implementation of expansionary fiscal policy as a means of fostering employment and growth. According to these constraints, budget deficit and public debt must not exceed respectively $3 \%$ and $60 \%$ of GDP. Table 1 also shows the evolution of budget deficit and public debt.

Table 1. A comparison of key economic indicators in the Euro area and the USA

\begin{tabular}{|l|c|l|l|l|l|l|l|l|l|l|}
\hline & \multicolumn{2}{|l}{ Growth rate } & \multicolumn{2}{l|}{ Unemployment } & \multicolumn{2}{c|}{ Inflation } & \multicolumn{2}{c|}{$\begin{array}{l}\text { Public Deficit } \\
\text { \% of GDP) }\end{array}$} & \multicolumn{2}{|c|}{$\begin{array}{l}\text { Budget Balance } \\
\text { (\% of GDP) }\end{array}$} \\
\hline & USA & $\begin{array}{l}\text { Euro } \\
\text { area }\end{array}$ & USA & $\begin{array}{l}\text { Euro } \\
\text { area }\end{array}$ & USA & $\begin{array}{l}\text { Euro } \\
\text { area }\end{array}$ & USA & $\begin{array}{l}\text { Euro } \\
\text { area }\end{array}$ & USA & $\begin{array}{l}\text { Euro } \\
\text { area }\end{array}$ \\
\hline 1999 & 4.7 & 2.7 & 4.2 & 9.3 & 2.2 & 1.1 & 58.0 & 72.4 & +1.3 & -1.3 \\
\hline 2000 & 4.1 & 3.8 & 4.0 & 8.4 & 3.4 & 2.1 & 54.1 & 69.9 & +2.3 & -1.0 \\
\hline 2001 & 1.0 & 1.9 & 4.7 & 7.9 & 2.8 & 2.3 & 55.5 & 69.2 & +1.2 & -1.9 \\
\hline 2002 & 1.8 & 0.9 & 5.8 & 8.3 & 1.6 & 2.3 & 57.7 & 68.5 & -1.4 & -2.6 \\
\hline 2003 & 2.8 & 0.7 & 6.0 & 8.7 & 2.3 & 2.1 & 59.2 & 69.8 & -3.2 & -3.0 \\
\hline 2004 & 3.8 & 2.3 & 5.5 & 9.2 & 2.7 & 2.1 & 60.4 & 69.6 & -3.3 & -2.9 \\
\hline 2005 & 3.4 & 1.7 & 5.1 & 9.1 & 3.4 & 1.5 & 61.0 & 70.2 & -2.4 & -2.6 \\
\hline 2006 & 2.7 & 3.2 & 4.6 & 8.3 & 3.2 & 1.5 & 61.7 & 68.5 & -1.8 & -1.3 \\
\hline 2007 & 1.8 & 3.0 & 4.6 & 7.5 & 2.9 & 2.1 & 62.8 & 66.3 & -1.1 & -0.7 \\
\hline 2008 & -0.3 & 0.4 & 5.8 & 7.6 & 3.8 & 3.3 & 73.5 & 70.2 & -3.1 & -2.1 \\
\hline 2009 & -2.8 & -4.5 & 9.3 & 9.6 & -0.4 & 0.3 & 84.5 & 80.0 & -9.8 & -6.4 \\
\hline 2010 & 2.5 & 2.1 & 9.6 & 10.2 & 1.6 & 1.6 & 92.1 & 85.6 & -8.6 & -6.2 \\
\hline 2011 & 1.6 & 1.5 & 8.9 & 10.1 & 3.2 & 2.7 & 96.4 & 88.0 & -8.4 & -4.2 \\
\hline 2012 & 2.2 & -0.9 & 8.1 & 11.4 & 2.1 & 2.5 & 100.8 & 89.3 & -6.7 & -3.7 \\
\hline 2013 & 1.7 & -0.3 & 7.4 & 12.0 & 1.5 & 1.4 & 100.9 & 91.4 & -4.1 & -3.0 \\
\hline 2014 & 2.4 & 1.2 & 6.2 & 11.6 & 1.6 & 0.4 & 102.2 & 92.0 & -2.8 & -2.6 \\
\hline 2015 & 2.6 & 2.0 & 5.3 & 10.9 & 0.1 & 0.0 & 103.4 & 90.3 & -2.4 & -2.1 \\
\hline 2016 & 1.6 & 1.8 & 4.9 & 10.0 & 1.3 & 0.2 & 105.6 & 89.2 & -3.1 & -1.5 \\
\hline
\end{tabular}

Source for European data: ECB Monthly Bulletin, 2000-2014; ECB Economic Bulletin 2017, vol 5. 
Economic data: https://fred.stlouisfed.org/series/FYFSGDA188S-

Statista: https://fr.statista.com/statistiques/550264/etats-unis-taux-d-inflation/

Bureau of Labor Statistics: https://data.bls.gov/timeseries/LNU04000000?periods=Annual+Data\& periods_option=specific_periods\&years_option=all_years

Note: Public deficit and budget balance are expressed as \% of GDP. A + sign indicates a surplus whereas - sign indicates a deficit.

It is possible to analyze the period 1999-2016 in two sub-periods: the first sub-period covers 1999-2007 and is characterized by the absence of significant economic crises whereas the second sub-period covers 2008-2016 marked heavily by the negative effects of the financial crisis in both regions.

As seen in Table 1, during 1999-2007, the ECB succeeded in maintaining the inflation rate close to or lower than its target level of $2 \%$. European inflation is lower than the American inflation and also less volatile. Nevertheless, inflation in the USA remains relatively low despite the fact that contrary to the $\mathrm{ECB}$, price stability is not Fed's priority objective.

The ECB's rigorous anti-inflationist policy and the Stability and Growth Pact allowed the stabilization of the public debt-to-GDP ratio albeit at a level relatively close to $70 \%$, higher than the upper limit of $60 \%$. Inspection of Table 1 shows that public debt is also stable in the USA during the same period ${ }^{2}$. Fiscal discipline allowed to maintain the budget deficit below the upper limit of $3 \%$ of GDP set by the Treaties. The temporary deviations in several countries during 2003-2004 are quickly taken under control. Despite a more relaxed fiscal discipline, the USA achieved a budget surplus for three years and a budget deficit lower than the euro zone for two years. For the rest of the first subperiod, the budget deficit in the USA is higher than in the EMU but remains stable at an acceptable level. Possibly, the higher growth rate in the USA contributed to the stabilization of the budget deficit through higher tax revenues implied by the higher growth rate. Moreover, these tax revenues allowed partially to stimulate public demand fostering thereby economic growth. Higher rate of growth in the USA helped reduce unemployment to a level significantly below the European unemployment rate. European unemployment is especially high in 1999. Indeed, the majority of the EMU members had to resort to restrictive economic policy in order to fulfil the Maastricht criteria, which allowed to achieve a moderate level of fiscal deficit and a low level of inflation in the euro area. However, EMU could not lower unemployment below 8\% except in 2001 and 2007. European unemployment exceeded 9\% three times whereas the USA managed to achieve an unemployment rate under $6 \%$ for the whole sub-period and lower than 5\% for the last four years of the period.

2 European public debt comprises the State and local administrations whereas American public debt comprises only the federal State's debt. This implies that they cannot be compared regarding their level. Therefore, the comments concern the evolution of the public debt in the two regions and not their levels. 
Starting from 2008, the financial crisis in the USA spread to Europe and the real sector. The propagation of the crisis led to a recession in Europe but less severe than in the US. Given the situation, the European Commission proposed a stimulus plan in 2008 which was to be implemented mainly at the national level (European Commission, 2008). This stimulus plan allowed to achieve a growth rate of $2.1 \%$ in 2010 . However, the cost of the stimulus plan combined with the negative effect of the recession on tax revenues brought about an increase in budget deficit and public debt in 2009 and 2010. Consequently, thinking that the economic recovery had started, the European Commission called for fiscal discipline and asked member countries to start respecting the Maastricht criteria. Thus member countries are induced to pursue restrictive fiscal policy, which allowed to reduce their budget deficits and to slow down the increase in public debt. On the other hand, restrictive fiscal policy had a negative effect on demand and thereby on growth. During 2012-2013 a negative growth rate and high unemployment are observed. Unemployment rate peaks at $12 \%$ in 2013 and does not fall below 10\% before 2016 due to the low growth rate.

The economic crisis hit particularly hard several European countries such as Greece and Portugal. The resulting recession worsened public finance. The rating agencies reduced the credit note of those countries which triggered a sovereign debt crisis amplified by the high interest rates for public borrowing due to the increased risk premium. These countries had to call for financial aid which is provided by the Troika (European Commission, ECB and FMI). The latter imposed restrictive policies and austerity plans on those countries.

In contrast to Europe, the USA set employment as the priority objective and continued the fiscal stimulus plan coupled with expansionary monetary policy (Koenig, 2013:4). Accordingly, the American growth rate remains above the growth rate in the euro area (except in 2016) and unemployment falls significantly, which in 2016, corresponds roughly to half of the unemployment rate in the euro area. The budget deficit observed in 2010-2011 can be interpreted as a sign of the persistent fiscal stimulus policy. The reduction in the budget deficit in the following years is achieved, at least partially, with the increase in tax revenues implied by the relatively high income growth.

While Table 1 gives the average values for the euro area, economic outlooks can diverge significantly from one member country to the other. Indeed, in 2016, the growth rate for Malta is 5.5\% whereas Italy grows at the rate of $0.9 \%$ and Greece is in recession with $-0.2 \%$ (Eurostat, May 2017). As for the unemployment rate, the gap is even wider with $4.1 \%$ in Malta, $3.9 \%$ in Germany, 23.5\% in Greece and 18.5\% in Spain. While one third of the member countries report an unemployment rate higher than the average, unemployment in the other one third remains between $7 \%$ and $10 \%$. 
In the euro area, average unemployment among the young population is 20.1 per cent in 2016 and it also varies significantly from one country to the other. Specifically, 44 per cent of the member countries report a higher unemployment rate among young population than the average with a peak of $46.7 \%$ in Greece and $42.1 \%$ in Spain respectively. On the other end of the distribution we can see Germany and Netherlands with respectively $3.8 \%$ and $9.8 \%$. Given these data on the unemployment rate in the euro zone, it is not surprising to see that unemployment is reported as the main concern of the European citizens according to a survey of Eurobarometer (2014, p.39).

The European Commission assumes that by strengthening the fiscal discipline it will be possible to improve public finance towards reasonable levels and ensure thereby the conditions for a sustained growth. Moreover, by reforming the governance in the euro zone, the Commission hopes to provide an institutional frame better adapted to the current management of the economy as well as instruments allowing for a better management of economic and financial crises in the future.

\section{Increasing Fiscal Discipline}

According to the European Commission, fiscal discipline as defined by the Stability and Growth Pact (SGP) was not respected by the member countries during the period 1999-2007 since public debt exceeded the target level of 60 per cent of GDP. Indeed, the European Commission considers that despite the relatively high unemployment and the modest growth rate between 1999 and 2007, the macroeconomic conditions were sufficiently suitable for achieving the required public debt target. Therefore, according to the European Commission, the fact that the member countries exceed the target level for public debt is mainly due to the excessive budget deficit in several countries like Germany and France in 2002 and 2003 as well as to the relaxation of the SGP in 2003 and 2005 following the difficulties of implementation observed in the member countries. However, the exceeding level of public debt is also likely to be triggered by the fall in the growth rate during 2002 and 2003 rather than the lack of fiscal discipline in several member countries. The will to restore a more rigorous budget discipline in times of low economic fluctuation is encouraged by the worsening of public finance following the 2008 crisis and the fiscal stimulus plan that the crisis brought about. Therefore, measures have been taken in order to strengthen the SGP. However, the strengthening of the SGP should not only improve public finance but should also promote economic growth according to the Commission.

\section{The Strengthening of the Stability and Growth Pact}

The SGP is strengthened by rules specified in three categories of legislation: 
- A set of five regulations and one directive composing the six-pack (December, 2011)

- A second set of two regulations composing the two-pack (May, 2013)

- The fiscal compact (January 2013) defined in the title 3 of the Treaty on Stability Coordination and Governance (TSCG)) which is binding for all the members of the euro area plus three non-member countries of the euro area.

The aim of these additional regulations is to reinforce supervision and fiscal discipline. They imply policy measures regarding fiscal rules, the prevention of a worsening of public finance and the modalities of national budget preparation.

The fiscal compact introduces a golden rule of public finance. According to the golden rule, the public administration budget must be balanced in each member country. This condition is met when the structural deficit does not exceed $0.5 \%$ of the GDP. If members do not fulfil this condition financial sanctions may apply. This permission for a structural deficit should allow the governments to increase public investment expenditures in order to induce economic growth. However, in practice, this rule is difficult to implement due to problems related to the statistical computation of the structural balance (Sterdyniak 2015). Indeed, in order to determine the structural balance one must determine the difference between the global budget balance and its cyclical component, which requires estimating the output gap (Jahan and Mahmud 2013). The estimation of the potential GDP necessary to estimate the output gap varies with the method applied. Consequently, the level of the structural deficit could vary across analyzes provided by different institutions.

The following terms of the six-pack and the two-pack intend to prevent the worsening of public finance:

- A modification of the decision procedure on the possible sanctions in case of excessive deficit. According to the new procedure, the sanctions against a member are imposed as a result of reverse qualified majority voting instead of qualified majority voting. In the former, the sanction applies unless the qualified majority reveals against, which reduces the chance of members to escape from a sanction.

- The reinforcement of the control and supervision of the members who benefit from a European financial assistance programme in times of crisis, such as Greece.

- The introduction of the excessive imbalance procedure based on a number of criteria which trigger a mechanism of recommendations from the Commission and the Council in order to reduce the imbalances. This 
is the procedure that led to the consideration of Germany's current account surpluses as excessive. Hence Germany has been subject to this procedure in 2013 since those surpluses were likely to cause an appreciation of the euro, which is not advantageous to many European countries.

- A single procedure for the preparation of the national budgets based on rules with a common calendar. The Commission gives opinion on the national budget projects and eventually asks for modifications before submission to national parliaments.

\section{Budget Consolidation and Economic Growth}

Budget consolidation programmes aim at restoring a rigorous budget discipline. While these programmes are adopted voluntarily by most of the member countries especially since 2012 , they are imposed on the members in difficulty requiring financial assistance. These programmes are used for improving public finance without having too strong negative effects on short run output. Budget consolidation is believed to have expansionary effects based on the Ricardian equivalence assumption. Following a fall in public spending, households will anticipate a reduction in the future fiscal burden, which will induce them to increase consumption expenditures since they will not need to save in the current period in order to finance higher future taxes due to public debt service. Moreover, the fall in public spending will bring about a fall in public debt, which will decrease the interest rate and thereby stimulate private investment. Thus, the initial negative effect of a lower public spending on output may be partially or totally counterbalanced by the positive effect of higher private investment that the spending cut brings about. Therefore, according to the European Commission, there is no paradox in imposing budgetary consolidation on the countries going through a recession. The structural reforms which often accompany the consolidation programmes are expected to improve the business cycles in the medium or long run.

Consolidation programmes helped reduce average public deficit in the euro area to fall below 3\% of GDP after 2014 without however a significant improvement of the public debt-to-GDP ratio. In contrast, average growth rate in the euro area remains modest and the unemployment rate remains relatively high, suggesting that the economic performance did not improve significantly. The structural reforms imposed by the consolidation programmes on the member countries receiving financial assistance consist mainly of measures that are likely to reduce the share of public sector, such as privatizations, and to increase the degree of competition through wages and prices. Those structural reforms imply non-negligible social costs without a significant improvement in public finance. For example, the unemployment rate in Greece has increased 
from $10 \%$ in 2004 to $19 \%$ in July 2018 after a number of budget consolidation programmes (Eurostat 2018). Moreover, Greece has lost roughly a quarter of its GDP in recent years while the public debt-to-GDP ratio remained above 170 per cent. In contrast, Portugal, who has implemented restrictive fiscal policy until 2015, switched to a less restrictive fiscal policy following a change in the government. During the last two years, Portugal managed to improve the state of the public finance, reduce unemployment below the euro area average and achieve a growth rate of $2.6 \%$ in July 2018 .

The poor efficiency of these consolidation programmes are most probably due to the underlying assumptions which are not empirically validated. Indeed, the assumption of a weak output multiplier for public spending is rejected by various empirical studies. Based on seven different frameworks including the one used by the European Commission, Coenen et al. (2012) show that cutting public spending by $1 \%$ of GDP leads to a fall in GDP between 0.9 and 1.3 per cent. Similar results are reported in a recent study published by the IMF (2012: 42-43) indicating that the effect of restrictive fiscal policy on output in Europe, measured by the fiscal multiplier, has been underestimated. Indeed, the same study shows that budget consolidation programmes implemented in Europe were based on the assumption of a fiscal multiplier around 0.5 whereas the empirical estimations vary from 0.9 to 1.7 . Similarly, several empirical studies such as Alesina and Perotti (1997) show that the magnitude of the effects of a budget consolidation depends on whether the consolidation is achieved through public spending cuts (as implemented in Europe) or through higher taxes. Finally, budget discipline policies may reveal ineffective or even countereffective if implemented during economic recessions or economic slowdowns.

The comparison of the economic performance in the euro zone to that of the USA who decided to stick to the fiscal stimulus plan after 2011, suggests a policy alternative for Europe. In the USA, priority is given to growth and employment. In case of high growth and employment, public finance will improve automatically as tax revenues increase and social expenditures such as unemployment benefits decrease. The policy implemented in the USA allowed for a lower unemployment rate compared to Europe while significantly improving the public finance.

\section{The Steering of the Euro Area}

In 2017 the European Commission published a white paper on the future of Europe with various scenarios for the European Union by 2025 (European Commission 2017). The white paper was preceded by various reports published by European institutions on the future of the economic and monetary union. Among these reports, the five presidents' report (European Commission 2015) and the report of the European Council (Van Rompuy 2012) with a detailed 
project are worth mentioning. These reports suggest several reforms in order to improve the steering of the euro area. Indeed, the financial and economic crisis in 2008 revealed more clearly than ever before an insufficient management of the euro area as well as the absence of effective means for fighting against such a severe shock.

\section{Steering Problems in the Euro Area}

Normally, monetary policy conducted by a central bank and fiscal policy pursued by a Treasury acting on behalf of the government are the most common methods for managing financial crises. The monetary policy in the euro area is conducted by the European Central Bank which fulfilled the role of lender of last resort following the crisis injecting a considerable amount of money on the interbank market in order to prevent a possible credit crunch. However, the euro area does not have a government. Thus, the responsibility of managing an economic crisis is quite diffuse in the sense that it is unknown which European institution will be in charge of economic stabilization. The inconveniences related to this institutional uncertainty have manifested themselves especially when a bail-out of the European banks was revealed necessary.

The financial crisis in the USA propagated to the European banks due to the share of junk assets in the balance sheet coming from the USA banks. Thus, some of the European governments felt the need to support the banking system in order to avoid bank runs as well as a credit crunch. However, due to the absence of an enforced solidarity, governments have taken often divergent actions.

After a period of trial and error, governments in the euro area took the initiative of defining the general outline of a bail-out plan for the banking system and the implementation is confined to the member countries (Kowalsky and Schachmurove $2014: 44-45)$. This initiative can be interpreted as a modest advance towards cooperation at the European level since the implementation of the bail-out plan manifests divergence among countries regarding the governments' commitment as well as the degree of control on the banking sector activity. This initiative has been much criticised as it was taken according to a procedure that was not defined in the European Treaties and by an organization that was not officially recognized.

The conditional financial assistance programmes granted to member countries with economic and financial difficulties such as Greece, Portugal and Ireland received similar criticisms on the same basis. Indeed, the application of these programmes is confined to a troika composed of the independent ECB, the IMF and the European Commission. The latter is appointed by the Eurogroup which is a non-official institution, assembling the finance ministers 
of each member of the euro area in order to negotiate on its behalf and supervise the implementation of the assistance programme.

This type of solution to the economic crisis in the euro area raised questions especially on the legitimacy of the European policy makers as well as on the conformity to the European Treaties. Indeed, main decisions are taken by the national policy makers who are accountable towards the parliament at the national level instead of the European Parliament. This points out to an intergovernmental method which conflicts with the supranational decision making procedure defined by the article 294 of the Treaty on the functioning of the European Union. This supranational approach is the one that should be used for all decisions concerning the euro area. It requires the intervention of the main European institutions.

In order to revive the supranational approach for the steering of the euro area, as well as to increase its efficiency, the European Commission offered to create a European ministry of economy and finance.

\section{Creating the European Ministry of Finance and Economy}

Recently, in his state of the Union address, the president of the European Commission has revived the former project of creating the European ministry of finance and economy (Junker, 2017b). The authority of the European minister of finance could be justified from the institutional viewpoint by bringing together the functions of the vice-president of the European Commission and those of the president of the Eurogroup. Thus, the decisions would result from the combination of inter-governmental and supragovernmental approaches. Moreover, the minister's legitimacy could be established through full responsibility towards the European Parliament.

The idea of creating such a ministry is generally accepted. However, the content of its function is subject to numerous debates. The following functions are put forward by the European Commission and by Delors Institute (Henderlein and Haas, 2015).

- Strengthen policy coordination and control fiscal and financial rules. The idea of policy coordination is mainly an ex-ante coordination based on the SGP, the excessive deficit procedure and the procedure regarding macroeconomic imbalances;

- Assurance for compliance to the rules and the application of sanctions in case of violation. The minister will report on his/her actions to an institution with mixed composition of the parliament members both at the European and national level; 
- Participation to the management of economic crises by defending the interests of the euro zone during the negotiations, which, until now, have been carried out only at the intergovernmental level such as the agreements signed with the Prime Minister of Greece;

- Help the members having country-specific difficulties such as those resulting from asymmetric foreign shocks or from the necessity of improving the budget balance. This financial assistance may also allow the member countries to adapt to the European standards through structural reforms that would be difficult to implement with the country's own resources. The financial assistance can also take the form of a support for public investment.

- Institutional and juridical representation of the euro area at the international level together with the ECB in their respective domain of competence.

According to the governor of the French central bank, in order to exercise these functions, the minister should be supported by a Treasury at the European level making use of the expertise of the European Commission and an independent advisory board on economic issues (Villeroy de Galhau, 2017). The Commission offers to create a new budget line within the EU's budget while others advocate for the creation of a separate budget for the euro area subject to control from an organism composed of the representatives of the euro area.

The resources of this budget should not be used only or mainly for transfers to the less developed members, as feared by several politicians exercising at the national level. Instead, this budget should potentially support all the members of the euro area in order to improve economic convergence. The revenues of the budget could be used especially to help members suffering from a countryspecific shock, to accompany the future members through the pre-accession process and to support the implementation of structural reforms regarding digital technology and energy transition. The budget could also support an unemployment insurance system in the longer run at the European level according to the governor of the French central bank (Villeroy de Galhau, 2017). The expenditures in the budget should be financed by European taxes and by issuing a common bond.

This fiscal reform should be accompanied by institutional reforms which would provide the minister with the necessary policy instruments in order to allow for an effective administration of the euro area. 


\section{Instruments for Steering}

Once installed, the European minister of finance and economy must be endowed with the necessary instruments to reduce the risk of a new crisis in the banking system as well as the risks implied by the sovereign debt of the members and to improve the crisis management if a shock occurs. Two institutional innovations are considered in order to achieve these targets: stabilization organisms to provide help to members in difficulty and a banking union.

\section{Organisms in Charge of Financial Assistance to Members with Financing Difficulty}

The EMU had to support the members having economic problems following the public debt crisis after 2008. However, a financial assistance was ruled out by the no-bail-out clause in the Treaty on the Functioning of the European Union. Thus, this clause had to be got around by re-interpreting another clause of the Treaty which authorizes financial assistance to other members under exceptional circumstances. The European Financial Stability Facility (EFSF) is established on this juridical basis in 2010. The EFSF is an intergovernmental organism, which can lend to member States and buy government bonds on the secondary market. These lending activities of the EFSF are financed by issuing bonds that are guaranteed by members of the euro zone in proportion to their participation in the EFSF's capital. In January 2011, the EFSF's role is complemented by the creation of the European Financial Stabilization Mechanism (EFSM) which is a supranational device. The financial assistance provided by the EFSM is financed by the European Commission's borrowings with EMU's budget as the collateral.

Both EFSF and EFSM are replaced by the European Stability Mechanism (ESM) after the revision of the article 136 in the Treaty on the Functioning of the European Union. This revision explicitly authorizes the members of the euro zone to help the countries whose economic situation puts in danger the economic stability of the euro zone as a whole. Indeed, five countries (Ireland, Spain, Portugal, Cyprus and Greece) have received funding from the ESM which holds more than $55 \%$ of the Greek public debt. The ESM's funding capacity corresponds roughly to $4.5 \%$ of the GDP of the euro area in 2017. Given that some of the loans from the ESM can be used to recapitalize banks directly, which may imply non-negligible amounts ${ }^{3}$, the lending facilities of ESM may not be sufficient against a common shock in the euro area.

${ }^{3}$ For example, the State aid to banks in the EU was around 44\% of the GDP in 2013 although only about a quarter was used (Voszka 2017:98). 
The ESM is of intergovernmental nature operating under the international public law, not under the European Union's relevant code. Indeed, ESM's capital is held by the member States and the decisions are taken unanimously by a council composed of the finance ministers of the member countries. Receiving a financial assistance from the ESM is conditional on the implementation of a macroeconomic adjustment programme which is monitored by the European Commission. However, it is the board of directors of the ESM who decide whether to withhold the disbursements based on the European Commission's report. The ESM assures the full financing of a member country that has applied for financial assistance and buys public bonds in order to avoid liquidity problems in certain countries. Due to the intergovernmental nature of the ESM, it is likely that following a severe crisis, certain members may oppose to bearing the risk of a default on loans granted by the ESM. Such uncertainties may give rise to a mistrust of the lenders on the financial market, which could make it difficult to provide financial assistance to the members having economic and financial problems.

Considering that the ESM might fail to assure the efficacy of the role of the European Minister of Economics and Finance due to a lack of sufficient legal justification in the European Treaties, the president of the Commission offered creating a European Monetary Fund (EMF) in 2019. The idea of EMF was inspired by Gros and Mayer (2017) and Sapir and Schoenmaker (2017) among others.

The EMF would result from the transformation of the ESM with intergovernmental nature to a supra-governmental organism whose board of directors would be accountable to the European Parliament. The EMF would preserve the main fields of intervention as the ESM and could even play the role of a lender of last resort for banks in difficulty should the financial assistance mechanism offered by the European Banking Union prove insufficient. The proposition of creating a European Monetary Fund is not shared by some of the German politicians who would prefer to keep the intergovernmental structure and limit the Fund's role to the close control of the public budgets at the national level. Indeed, it is feared that the creation of a monetary fund might encourage governments for excessive borrowing induced by the anticipation of a bail-out in case of a default. The risk of excessive borrowing in anticipation of a bail-out is mentioned by Wyplosz (2017) who analyzes upon the European Parliament's demand, the advantages and inconveniences of such a monetary fund. According to Wyplosz (2017), the idea of a European monetary fund is motivated mainly by the desire to become independent of the IMF by creating a similar structure specific to Europe. 


\section{European Banking Union}

Following the propagation of the U.S financial crisis to European banks, the EU had to provide State aid to the banks in the form guarantees and recapitalization. Member countries showed great differences regarding the amounts of recapitalization (Voszka 2017:101). For example between 2008 and 2013, the recapitalization in top ten EU countries amounted to 423 billion euro where as the total recapitalization in EU as a whole was around 448 billion euro. This divergence made it more difficult to act quickly at the European level which led to the initial weaknesses of the crisis management in the banking sector. Consequently, the European authorities realized the necessity of a better regulation and supervision of the financial sector within an integrated financial system at the European level. For this, the president of the European Council prepared, in 2012, a roadmap towards a banking union. This banking union is based on three pillars given below:

- A single supervisory mechanism (SSM) is introduced by The Council Regulation $n^{\circ} 1024 / 2013$ of 15 october 2013. It is operative since 2014 under the responsibility of the ECB in cooperation with the national financial supervisory authorities. Its role consists of controlling on a regular basis and eventually sanctioning the main banks in the euro area based on a common regulation regarding the prudential requirements for banks.

- A single resolution mechanism (SRM) for failing banks established in 2016. SRM is composed of a resolution board which will determine the actions and a single resolution fund (SRF). Before applying for assistance from the SRF, banks with difficulties must resort first to the contributions of their shareholders-lenders, and depositors of over 100 000 euro. This condition is introduced to protect the tax-payers from bearing the cost of bank bailouts, in contrast to the previous experiences.

- A European deposit insurance scheme (EDIS) in order to maintain the viability of the banking system from the depositors' point of view. In 2015, the European Commission presented a project on a European fund of deposit guarantee for deposits less than 100000 euros, which should replace progressively the system of national deposit guarantee schemes. This fund will be financed by banks in proportion to the amount of deposits they hold. This third pillar of the banking union is not yet established due to the reluctance of several members like Germany. Indeed, the countries having already solid protection systems fear the possibility that their contributions might profit only to countries with a weak protection of depositors. 
The aim of the banking union is to avoid a divergence of the bank risks within the EU as well as the recurrence of a banking crisis. Indeed, the Council Regulation $n^{\circ} 1024 / 2013$ of 15 October 2013 states that the SSM should ensure that the union's policy relating to the prudential supervision of credit institutions is implemented in a coherent manner and contribute to the full internalization of all costs by banks caused by their activities. However, the fact that the banking union is currently incomplete brings about a risk of raising doubts on Europe's capacity to manage a future banking crisis without the public sector bearing the cost of bailouts.

\section{Conclusion}

Despite the unsatisfactory economic performance of the euro area, especially regarding employment, the European Commission maintains the improvement of public finance as the priority objective. The Commission considers that the presence of automatic fiscal stabilizers is sufficient for smoothing economic fluctuations in normal periods. Any stabilization of business cycles should be carried out in total respect of a strong budget discipline. Thus, temporary deviations from the allowed levels of public deficit as observed in 2002 and 2003 are no longer possible. However, a modest level of structural deficit is considered acceptable in order to stimulate public investment. This order of priorities differs from those of the U.S whose economic performance regarding employment is obviously better than the performance of the euro area. The European citizens also report a different order of priority from that of the Commission. Indeed, according to a survey of Eurobarometer on the public opinion (Eurobarometer 2014: 40), unemployment seems to be the main concern of the citizens, far before the public debt ${ }^{4}$.

Nevertheless, the European Commission admits that automatic stabilizers may reveal insufficient in case of severe shocks with a great amplitude. In this case, absorption of the shock may require a policy reaction at the European level through a risk sharing mechanism within the euro area. For this, the European Commission suggests establishing a safety net through higher financial integration and banking union. To be able to react to particularly severe shocks, as the one which hit Europe in 2008, the Commission introduced a number of reforms that should lead to a fiscal union. Consequently, the urgent installation of the institutions in charge of financial stabilization gave birth to the ESM. In the last phase of the integration process, the latter should evolve to a European monetary Fund of supra-governmental nature according to the

\footnotetext{
${ }^{4}$ According to this survey, between 2010 and 2014 unemployment was the main concern for more than 40 per cent of the respondents while public debt represents the main concern for approximately $10 \%$ of the sample. In 2014, unemployment is the primary concern in 23 countries in the EU. As of 2017, unemployment is still the primary concern while public debt is still the least concern of the European citizens (Eurobarometer 2017, p.10).
} 
Commission's project. The banking union should be managed by the European Minister of Economy and Finance, who would constitute the fiscal equivalent of the ECB in charge of the monetary sphere.

These institutional innovations are likely to take time to be fully established. For example, the banking union will only be complete when some of the member countries will withdraw their opposition. As for the implementation of a genuine fiscal union, it is necessary for the member countries to renounce partially fiscal and budgetary sovereignty. Eliminating these impediments will improve Europe's capacity to cushion financial shocks in the future. However, as long as the unemployment problem in the euro area is not urgently dealt with through a fiscal policy at the European level, the increasing mistrust among the European citizens will remain at high levels hindering the future of the EMU. 


\section{References:}

Alesina, A. and Perotti, R. (1997) "Fiscal Adjustments in OECD Countries: Composition and Macroeconomic Effects", IMF Staff Papers, 44 (2): 21048.

Coenen, G. et al. (2012) "Effects of Fiscal Stimulus in Structural Models", American Economic Journal: Macroeconomics, 4 (1): 22-68.

Enderlein, H. and Haas, J. (2015) "Quel Serait le Rôle d'un Ministre Européen des Finances? Une Proposition", Jacques Delors Institut Policy Paper 145, Jacques Delors Institute, Berlin.

ECB (2010-2014) Monthly Bulletin, European Central Bank, Frankfurt.

ECB (2017) Economic Bulletin, vol 5, European Central Bank, Frankfurt.

European Commission (2008) A European Economic Recovery Plan, Communication from the Commission to the European Council.

European Commission (2015) Completing Europe's Economic and Monetary Union, Five President's Report, June 22.

European Commission (2017) White Paper on the Future of Europe-Reflections and Scenarios for EU 27 by 2025, COM 2017/2025, March 1.

Eurostat (May 2017) Euro indicators, News Release 75/2017.

Eurostat (October 2018) Euro indicators, News Release 170/2018.

Gros, D. and Mayer, T. (2017) "A European Monetary Fund-Why and How", Center for European Policy Studies Working Document 2017/11, Center for European Policy Studies.

IMF (2012) "Coping with High Debt and Sluggish Growth", World Economic Outlook, International Monetary Fund, October 2012, Washington DC.

Jahan, S. and Mahmud, A. S. (2013) “What is the output gap?", Finance and Development, 50 (3): 38-9.

Junker, J. C. (2012) “Complete Europe’s Economic and Monetary Union”, Five presidents report, European Commission.

Junker, J. C. (2017a) "Reflections and scenarios on future of Europe-EU27 by 2026", European Commission.

Junker, J. C. (2017b) State of the Union Address 2017, European Commission.

Koenig, G., (2013) "Les Stratégies et les performances Américaines et Européennes en période de crise", Bulletin de l'observatoire des politiques économiques en Europe, (28): 12-7. 
Kowalsky, T. and Schachmurove, Y. (2014) "The reaction of the U.S. and the European Monetary Union to the recent global financial crises", Global Finance Journal, 25(2): 27-47.

Sapir, A. and Schoenmaker, D. (2017) "The time is right for a European Monetary Fund", Bruegel Policy Brief, (4):1-8.

Standard Eurobarometer 81 (2014) Public Opinion in the European Union, Report, Spring 2014, European Commission.

Standard Eurobarometer 88 (2017), Public Opinion in the European Union, First Results, Autumn 2017, European Commission.

Sterdyniak, H. (2015) "Faut-il encore utiliser le concept de croissance potentielle?", Revue de l'OFCE, (142): 255-90.

Van Rompuy H., (2012) Towards a Genuine Economic and Monetary Union, European Council, December 5.

Villeroy de Galhau, F. (2017) "The future of the euro area from the "impossible trinity" to the "growth triangle"", Speech by the Governor of the Banque de France at the "Brussels Economic Forum 2017", 6th Annual Tommaso Padoa-Schioppa Lecture, Brussels, 1 June 2017.

Voszka, E. (2017) "Nationalization or Privatization? The Fragmentation of the Mainstream”, Annals of Public and Cooperative Economics, (88) :91-120.

Wyplosz, C. (2017) “A European Monetary Fund?”, Directorate-General for internal policies, European Parliament, <www.europarl.europa.eu/.../20 17/.../IP OL_IDA(2017)602076_EN>. 